\title{
Nodules from Fynbos legume Virgilia divaricata have high functional plasticity under variable $P$ supply levels
}

\author{
Waafeka Vardien ${ }^{\mathrm{a}}$, Jolanta Mesjasz-Przybylowicz ${ }^{\mathrm{b}}$, Wojciech J. Przybylowicz ${ }^{\mathrm{b}, \mathrm{c}}$, Yaodong \\ Wang $^{\mathrm{b}}$, Emma T. Steenkamp ${ }^{\mathrm{d}}$, and Alex J. Valentine ${ }^{\mathrm{a}^{*}}$
}
${ }^{a}$ Department of Botany and Zoology, Stellenbosch University, Private Bag X1, Matieland 7602, South Africa
${ }^{\mathrm{b}}$ Materials Research Department, iThemba LABS, National Research Foundation, PO Box 722, Somerset West 7129, South Africa

${ }^{c}$ AGH University of Science and Technology, Faculty of Physics and Applied Computer Science, Al. A. Mickiewicza 30, 30-059 Krakow, Poland

${ }^{\mathrm{d}}$ Department of Microbiology and Plant Pathology, Forestry and Agricultural Biotechnology Institute (FABI), University of Pretoria, Pretoria 0002, South Africa

* Corresponding author: e-mail: alexvalentine@mac.com

Tel: (+27+21) 808-3067 Fax: (+27+21) 808-2405

\begin{abstract}
Legumes have the unique ability to fix atmospheric nitrogen $\left(\mathrm{N}_{2}\right)$ via symbiotic bacteria in their nodules but depend heavily on phosphorus $(\mathrm{P})$, which affects nodulation, and the carbon costs and energy costs of $\mathrm{N}_{2}$ fixation. Consequently, legumes growing in nutrient-poor ecosystems (e.g. sandstone derived soils) have to enhance $\mathrm{P}$ recycling and/ or acquisition in order to maintain $\mathrm{N}_{2}$ fixation. In this study, we investigated the flexibility of $\mathrm{P}$ recycling and distribution within the nodules and their effect on $\mathrm{N}$ nutrition in Virgilia divaricata Adamson, Fabaceae, an indigenous legume in the Cape Floristic Region of South Africa. Specifically, we assessed tissue elemental localization using micro-particle induced $\mathrm{x}$-ray emission
\end{abstract}


(PIXE), measured $\mathrm{N}$ fixation using nutrient concentrations derived from inductively coupled mass spectrometry (ICP-MS), calculated nutrient costs, and determined $\mathrm{P}$ recycling from enzyme activity assays. Morphological and physiological features characteristic of adaptation to P-deprivation were observed for $V$. divaricata. Decreased plant growth and nodule production with parallel increased root: shoot ratios are some of the plastic features exhibited in response to $\mathrm{P}$ deficiency. Plants resupplied with $\mathrm{P}$ resembled those supplied with optimal $\mathrm{P}$ levels in terms of growth and nutrient acquisition. Under low P conditions, plants maintained an increase in $\mathrm{N}_{2}$-fixing efficiency despite lower levels of orthophosphate (Pi) in the nodules. This can be attributed to two factors: i) an increase in Fe concentration under low P, and ii) greater APase activity in both the roots and nodules under low P. These findings suggest that $V$. divaricata is well-adapted to acquire $\mathrm{N}$ under $\mathrm{P}$ deficiency, owing to the plasticity of its nodule physiology.

Keyword index: Phosphorus-deficient, legume, root-nodule, resource-limited ecosystem, $\mathrm{N}_{2^{-}}$ fixation, adaptation, acid-phosphatase

\section{List of abbreviations:}

Biological Nitrogen Fixation (BNF), Nitrogen Derived from Atmosphere (\%NDFA), Relative Growth Rates (RGR), Specific Nitrogen Acquisition Rate (SNAR), Specific Nitrogen Utilisation Rate (SNUR), Specific Phosphate Acquisition Rate (SPAR), Specific Phosphate Utilisation Rate (SPUR), Acid Phosphatase (APase), Particle-induced X-ray Emission (PIXE), Proton backscattering (BS), Inductively Coupled Mass-spectrometry (ICP-MS).

\section{Introduction}

Soil phosphorus (P) availability is the most limiting factor for legumes that symbiotically fix atmospheric nitrogen $\left(\mathrm{N}_{2}\right)$ with rhizobia (Vance et al. 2003). $\mathrm{N}_{2}$-fixing legumes are 
autonomous at acquiring $\mathrm{N}$, but depend profoundly on and require more $\mathrm{P}$ than legumes growing on mineral N (Drevon and Hartwig 1997). Phosphorus not only affects the energy costs of $\mathrm{N}_{2}$ fixation (Schulze et al. 1999, Valentine et al. 2010), it is also important for nodule formation and function (Israel 1987). After N, however, P is often the most limited element in soils, especially in ancient sandstone-derived soils which are coarse-grained and highly leached such as soils encountered in the Cape Floristic Region (CFR) of South Africa (Witkowski and Mitchell 1987). The legume tree, Virgilia divaricata (Adamson) is native to the CFR, and is distributed over a wide range of variably P-poor soils, from relatively richer forest margins to poorer Fynbos soils (Coetsee and Wigley 2013).

Phosphorus is taken up as orthophosphate (Pi), but the chemistry of $\mathrm{Pi}$ results in low $\mathrm{Pi}$ concentrations in the soil solution, thus limiting Pi diffusion to the root system (Morgan et al., 2005). Many studies have investigated P in rhizobium-legume symbiosis (Israel 1993, HøghJensen et al., 2002, Olivera et al., 2004, Bucciarelli et al., 2006), and have demonstrated that improving $\mathrm{P}$ nutrition in legumes under P-deficient conditions is generally based on two broad mechanisms (Raghothama 1999, Hammond et al., 2003). These are (i) increasing P acquisition that can be accomplished by increasing carbohydrate allocation to the roots, which increases the root: shoot ratio or causes a shift from primary to lateral root growth (Vance et al., 2003) and (ii) enhancing $\mathrm{P}$ utilization by increasing the abundance of Pi transport proteins and the exudation of organic acids, as well as phosphatases to mobilize $\mathrm{P}$ from organic or insoluble compounds (Plaxton 2004). An alternative way to attain P from the soil for use in plant growth is through the use of acid phosphatases (APases) to hydrolyse organic P (Duff et al., 1994). In plant tissues, APases are mainly found in the cell wall and intracellular spaces (Yadav and Tarafdar 2001, Olczak et al., 2003). Extracellular APases are involved in breakdown of organic phosphate monoesters in the soil, whereas intracellular APases are thought to be pivotal in the remobilization and scavenging of Pi from intracellular 
phosphate monoesters (Duff et al., 1994, Marschner 1995). In common bean, the activities of APases increase in the nodules under low-P conditions, indicating that $\mathrm{N}_{2}$-fixing legumes can enhance P utilization within the nodules to tolerate P deficiency (Araújo et al., 2008).

The mechanistic effects of $\mathrm{P}$ limitation on $\mathrm{N}_{2}$ fixation are not fully understood and not much is known of P metabolism in nodules. This is despite the fact that legumes occur worldwide where they thrive under a diversity of ecological, including limited $\mathrm{P}$ and $\mathrm{N}$ availability. It is therefore reasonable to expect that even in nutrient-poor ecosystems legume species adapt to low $\mathrm{P}$ conditions or make use of alternate strategies to obtain and recycle $\mathrm{P}$ (He et al., 2011). Most studies on the effect of P limitation on $\mathrm{N}_{2}$-fixation have largely been confined to model legumes such as Lupinus albus (Schulze et al., 2006, Thuynsma et al., 2013) and Medicago truncatula (Tang et al., 2001, Sulieman et al., 2013). Despite the high legume diversity found on the P-poor soils of the CFR (Goldblatt and Manning 2002), little is known about the functional mechanisms which affect $\mathrm{N}$ nutrition within the nodules of indigenous legumes.

Our aim was therefore to investigate how $\mathrm{P}$ recycling and distribution in nodules, affect the $\mathrm{N}$ nutrition of the indigenous legume Virgilia divaricata, during variable P supply.

\section{Materials and methods}

\section{Seed germination, bacterial inoculation and growth}

Virgilia divaricata seeds (Silverhill Seeds, Kenilworth, South Africa) were placed in smoke solution (Smoke Plus, Kirstenbosch National Botanical Garden, South Africa) (Magadlela et al. 2014) and incubated in a water bath at $50^{\circ} \mathrm{C}$ for $4 \mathrm{~h}$. Thereafter seeds were surface sterilised, rinsed with distilled water and germinated in $5 \mathrm{~cm}$ deep seed trays containing sterile sand under natural light conditions (midday irradiances between $600-800 \mu \mathrm{mol} \mathrm{m}^{-2} \mathrm{~s}^{-1}$ ) in a temperature controlled $\left(15-25^{\circ} \mathrm{C}\right)$, north-facing greenhouse at Stellenbosch University, South Africa. 
After the first fully expanded leaf emergence, seedlings were transferred to pots containing sterile sand and inoculated with Burkholderia. Inoculum was prepared by growing the bacterium on yeast mannitol agar (YMA) containing $0.5 \mathrm{~g} / \mathrm{L}$ yeast extract (Biolab), $10 \mathrm{~g} / \mathrm{L}$ mannitol (Saarchem), $0.5 \mathrm{~g} / \mathrm{L}$ dipotassium hydrogen orthophosphate $\left(\mathrm{K}_{2} \mathrm{HPO}_{4}\right.$, Biolab), 0.2 $\mathrm{g} / \mathrm{L}$ magnesium sulfate heptahydrate $\left(\mathrm{MgSO}_{4} \cdot 7 \mathrm{H}_{2} \mathrm{O}\right.$, Biolab), $0.1 \mathrm{~g} / \mathrm{L}$ sodium chloride $(\mathrm{NaCl}$, Biolab), $15 \mathrm{~g} / \mathrm{L}$ bacteriological agar (Biolab) and $2.5 \mathrm{~g} / \mathrm{L}$ Congo red (Saarchem) (Somasegaran and Hoben 1994). After incubation at $28^{\circ} \mathrm{C}$ for 4 days, single colonies were selected and cultures prepared in Tryptone-Yeast medium containing $5 \mathrm{~g} / \mathrm{L}$ tryptone (Biolab), $3 \mathrm{~g} / \mathrm{L}$ yeast extract (Biolab) and $2 \mathrm{ml}$ of a $440 \mathrm{~g} / \mathrm{L}$ calcium chloride dihydrate $\left(\mathrm{CaCl}_{2} \cdot 2 \mathrm{H}_{2} \mathrm{O}\right.$, Biolab) solution (Somasegaran and Hoben 1994). After incubation for $24 \mathrm{~h}$ at $28^{\circ} \mathrm{C}, 50 \mathrm{ml}$ of the bacterial culture were applied to each seedling.

Plants were separated into three treatment groups: group I (low P, LP), group II (high P, HP, control) and group III (resupplied phosphate, RP: 4 weeks of low P followed by 4 weeks of high P). The plants in these groups were supplied with $100 \mathrm{ml}$ of a quarter strength Long Ashton nutrient solution (Hewitt 1966) twice a week. The nutrient solution was modified to contain either $500 \mu \mathrm{M} \mathrm{P}(\mathrm{HP})$ or $5 \mu \mathrm{M} \mathrm{P}(\mathrm{LP})(\mathrm{pH} 5.8)$ and $500 \mu \mathrm{M} \mathrm{NH} \mathrm{NHO}_{3}$. Plants were grown for 8 weeks under the same conditions as described for germination after which they were harvested.

\section{Specimen preparation for elemental analysis}

Nodule samples were immediately frozen by immersion in liquid propane cooled by liquid nitrogen, using a Leica EM CPC cryoworkstation (Leica Microsystems AG, Vienna, Austria). Samples were subsequently freeze-dried in a Leica EM CFD Cryosorption Freeze Dryer, following a $208 \mathrm{~h}$ programmed cycle starting at $-80{ }^{\circ} \mathrm{C}$, and ending at ambient temperature. Transverse sections of the freeze-dried nodule samples were obtained by hand-sectioning 
under a stereomicroscope using a double-edge stainless steel razor blade, and mounted between two layers of $0.5 \%(\mathrm{w} / \mathrm{v})$ Formvar film. To prevent charge build-up during measurements, the Formvar membrane facing the proton beam was coated with a thin layer of carbon. Light micrographs of each specimen were taken before and after proton irradiation.

\section{Elemental analysis and data evaluation}

Analyses were performed using the nuclear microprobe at the Materials Research Department, iThemba LABS, South Africa. A proton beam of $3 \mathrm{MeV}$ energy from the $6 \mathrm{MV}$ single-ended Van de Graaff accelerator, was focused onto a $3 \times 3 \mu \mathrm{m}^{2}$ spot and scanned over specimens using square or rectangular scan patterns with a variable number of pixels (up to $128 \times$ 128). Scan sizes varied according to the sizes of nodules. Particle-induced $\mathrm{x}$-ray emission (PIXE) and proton backscattering (BS) were used simultaneously. PIXE spectra were registered in the energy dispersive mode, using a Si (Li) detector. BS spectra were recorded with an annular Si surface barrier detector (100 $\mathrm{mm}$ thick) positioned at an average angle of $176^{\circ}$. Data were acquired in the event-by-event mode. The normalization of results was done using the integrated beam charge, collected simultaneously from a Faraday cup located behind the specimen and from the insulated specimen holder. A more detailed description of the nuclear microprobe set-up at iThemba LABS can be found in Prozesky et al., (1995) and Przybylowicz et al., (1999, 2001, 2005).

Data evaluation was performed using GeoPIXE II software (Ryan 2000). Quantitative elemental images were generated using the Dynamic Analysis method. The matrix composition and areal density were obtained from the analysis of corresponding BS spectra using a RUMP simulation package (Doolittle 1986) with non-Rutherford cross sections for C, $\mathrm{O}$ and $\mathrm{N}$. In addition to elemental images, average concentrations from nodules were also 
obtained. For this purpose PIXE and BS spectra extracted from the nodule cross sections were used.

\section{Biomass parameters and nutrient concentrations}

Upon harvesting, a subset of plants was separated into nodules, roots and shoots. The harvested material was dried at $50^{\circ} \mathrm{C}$ for $72 \mathrm{~h}$ and dry weights (DW) recorded. The latter were used to calculate growth parameters such as allocation and relative growth rate (RGR). The dried material was milled and analysed for their respective $\mathrm{C}$ and $\mathrm{N}$ concentrations at the Archeometry Department (University of Cape Town, South Africa) and P concentration at the Central Analytical Facility (Stellenbosch University, South Africa) using inductively coupled mass-spectrometry (ICP-MS).

\section{Calculations of $\delta^{15} \mathrm{~N}$}

The $\delta^{15} \mathrm{~N}$ analyses were also carried out at the Archeometry Department (University of Cape Town, South Africa). The isotopic ratio of $\delta^{15} \mathrm{~N}$ was calculated as $\delta=1000 \%$ $\left[\mathrm{R}_{\text {sample }} / \mathrm{R}_{\text {standard }}\right]$, where $\mathrm{R}$ is the molar ratio of the heavier to the lighter isotope $\left({ }^{15} \mathrm{~N}:{ }^{14} \mathrm{~N}\right)$ of the sample and standards as defined by Farquhar et al., (1989). Approximately $2 \mathrm{mg}$ of each dried organ sample was put into $8 \mathrm{~mm}$ by $5 \mathrm{~mm}$ tin capsules (Elemental Microanalysis Ltd., Devon, U.K.) on a Sartorius microbalance (Goettingen, Germany). The samples were then combusted in a Fisons NA 1500 (Series 2) CHN analyzer (Fisons Instruments SpA, Milan, Italy). The $\delta^{15} \mathrm{~N}$ values for the nitrogen gases released were determined on a Finnigan Matt 252 mass spectrometer (Finnigan MAT GmbH, Bremen, Germany), which was connected to a CHN analyzer by a Finnigan MAT Conflo control unit. \%NDFA was calculated according to Shearer and Kohl (1986):

$\% \mathrm{NDFA}=100\left(\left(\delta^{15} \mathrm{~N}_{\text {reference plant }}-\delta^{15} \mathrm{~N}_{\text {legume }}\right) /\left(\delta^{15} \mathrm{~N}_{\text {reference plant }}-\mathrm{B}\right)\right)$ 
The reference plant was non-nodulated Virgilia divaricata, grown under the same glasshouse conditions. The $\mathrm{B}$ value is the $\delta^{15} \mathrm{~N}$ natural abundance of the $\mathrm{N}$ derived exclusively from biological N-fixation of nodulated Virgilia divaricata, also grown under same conditions as the reference plants, but with a $\mathrm{N}$-free nutrient solution.

\section{Nutrient cost calculations}

The Specific $\mathrm{P}$ absorption rate (SPAR) $\left(\mathrm{mgP} \mathrm{g}^{-1} \mathrm{DW} \mathrm{d}^{-1}\right)$ reflects the net $\mathrm{P}$ absorption rate per unit root DW (Nielson et al., 2001) and was determined using the formula:

$$
\operatorname{SPAR}=\left[\left(\mathrm{M}_{2}-\mathrm{M}_{1} / \mathrm{t}_{2}-\mathrm{t}_{1}\right)\right] \times\left[\left(\log _{\mathrm{e}} \mathrm{R}_{2}-\log _{\mathrm{e}} \mathrm{R}_{1}\right) /\left(\mathrm{R}_{2}-\mathrm{R}_{1}\right)\right]
$$

where $\mathrm{M}$ is the $\mathrm{P}$ content per plant, $\mathrm{t}$ is the time and $\mathrm{R}$ is the root $\mathrm{DW}$. This equation was modified to calculate the net $\mathrm{P}$ absorption rate for nodules, where the nodule DW was used instead of root DW.

Specific $\mathrm{P}$ utilization rate (SPUR) $\left(\mathrm{g} \mathrm{DW} \mathrm{mg}^{-1} \mathrm{P} \mathrm{d}^{-1}\right)$ is a measure of the DW gained for the $\mathrm{P}$ taken up by the plant (Nielson et al., 2001) and was estimated with the following formula:

$$
\operatorname{SPUR}=\left[\left(\mathrm{W}_{2}-\mathrm{W}_{1} / \mathrm{t}_{2}-\mathrm{t}_{1}\right)\right] \times\left[\left(\log _{\mathrm{e}} \mathrm{M}_{2}-\log _{\mathrm{e}} \mathrm{M}_{1}\right) /\left(\mathrm{M}_{2}-\mathrm{M}_{1}\right)\right]
$$

where $\mathrm{M}$ is the $\mathrm{P}$ content of the plant and $\mathrm{W}$ is the plant $\mathrm{DW}$. This equation was modified to calculate the DW gained for the P uptake by roots and nodules, where the nodule and root DW was used instead of plant DW. The specific $\mathrm{N}$ absorption and utilization rates (respectively SNAR and SNUR) were adapted from this equation as well, to include $\mathrm{N}$ instead of $\mathrm{P}$.

Enzyme activity assay: Intracellular Acid phosphatase

To assess P recycling, fresh nodule and root samples detached upon harvesting were frozen at $-80^{\circ} \mathrm{C}$. Nodule and root samples (approximately $40 \mathrm{mg}$ fresh mass) were ground with an 
extraction buffer according to Araujo et al., (2008) consisting of $0.1 \mathrm{M} \mathrm{Na-acetate}$ and $1 \% \beta$ mercapto-ethanol. The material was centrifuged at $13,000 \mathrm{~g}$ at $4^{\circ} \mathrm{C}$ during $30 \mathrm{~min}$, and the supernatant was taken for enzyme assays. For APase activity, $200 \mu l$ of nodule or root crude protein extract was incubated for $30 \mathrm{~min}$ at $28^{\circ} \mathrm{C}$ with a mixture of $50 \mathrm{mM}$ Na-acetate buffer containing 5mM p-NPP (p-nitrophenyl phosphate). The reaction was stopped by the addition of $1.0 \mathrm{ml} 0.5 \mathrm{M} \mathrm{NaOH}$, and activity was measured spectrophotometrically at $410 \mathrm{~nm}$. APase activity was defined as the amount of p-NP (p-nitrophenyl) released relative to known $\mathrm{p}$-NP standards (derived from a standard curve) and expressed per unit protein.

\section{Statistical analysis}

The effects of the factors and their interactions were tested with an analysis of variance (ANOVA) (Kaleidagraph, Synergy Software, USA). Where the ANOVA revealed significant differences between treatments, the means (4-5) were separated using the post-hoc Tukey's LSD multiple range test (SuperAnova for Macintosh, Abacus Concepts, USA) $(\mathrm{P} \leq 0.05)$. Different letters indicate significant differences among treatments.

\section{Results}

\section{Nodule induction}

All $50 \mathrm{~V}$. divaricata plants grown, formed nodules and all subsequent results are based on nodules that were functionally fixing $\mathrm{N}_{2}$ (Figure 1a and c). Nodules were round-spherical in shape and often produced in clusters (Figure 1a and b). Most nodules formed at the top portion of the root system (Figure 1a).

\section{Biomass and allocation}

Total plant biomass accumulation decreased in P-starved plants as a result of root, shoot and nodule growth (Table 1). The period of resupply (RP) to previously P- starved plants, resulted 
Figure 1 Nodules of Virgilia divaricata (Adamson, Fabaceae). a) Nodules mostly occur at the top region of the root system and are typically b) clustered, occurring in groups of two or more. For the various analyses in this study, only active N2-fixing nodules were selected based on the presence of the pink coloration caused by leghemoglobin (red arrow) as seen in c).

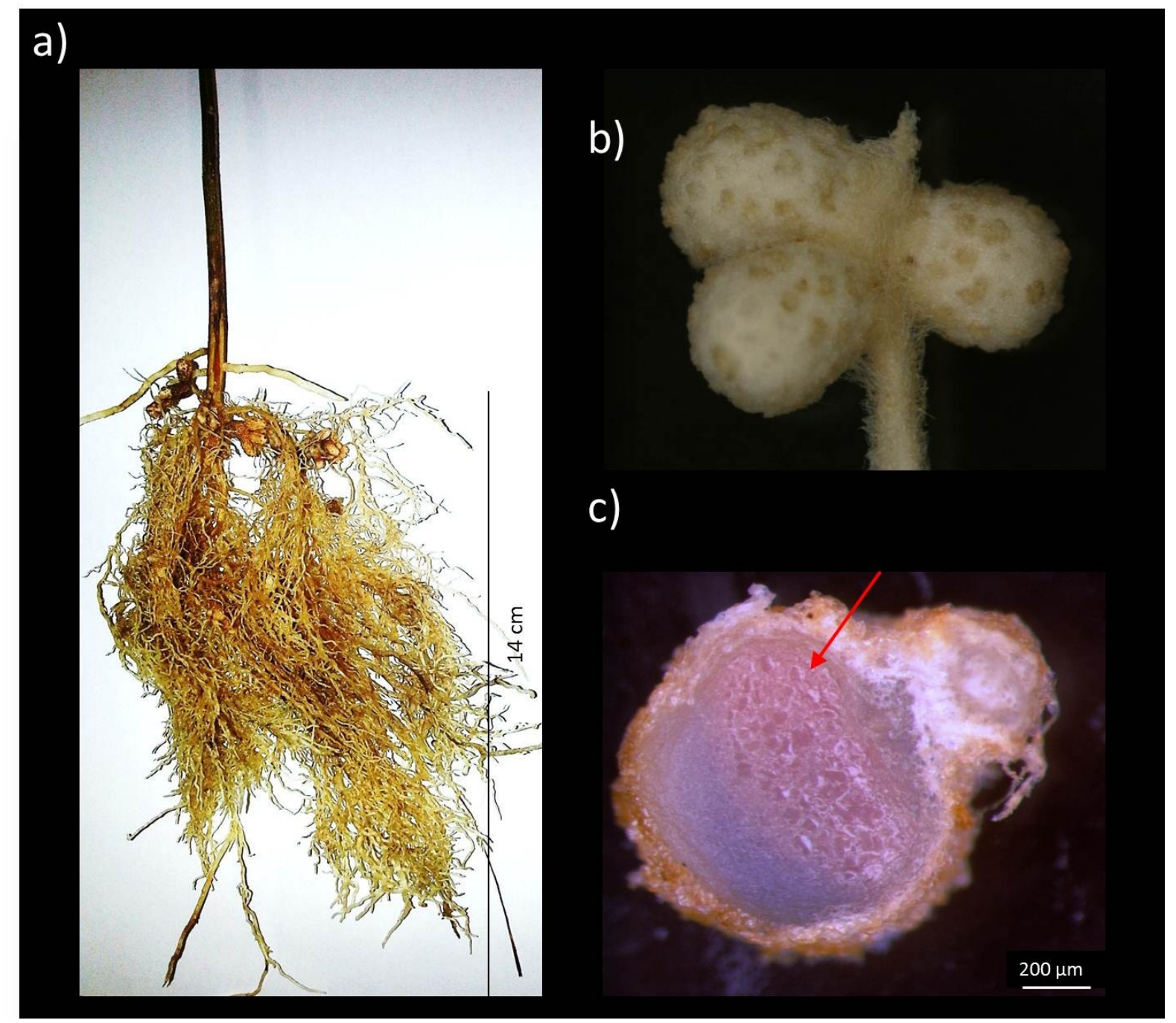


Table 1

Biomass of Virgilia divaricata (Adamson, Fabaceae) grown under adequate (HP), deficient (LP) and resupplied (RP) phosphorus conditions.

\begin{tabular}{lccc}
\hline & \multicolumn{3}{c}{ Phosphate treatment } \\
\cline { 2 - 4 } Parameters & $\begin{array}{c}\text { High } \\
(500 \mu \mathrm{M}, \text { control })\end{array}$ & $\begin{array}{c}\text { Low } \\
(5 \mu \mathrm{M})\end{array}$ & $\begin{array}{c}\text { Resupplied } \\
(5 \mu \mathrm{M} ; 500 \mu \mathrm{M})\end{array}$ \\
\hline Plant dry weight $(\mathrm{g})$ & $1.166 \pm 0.08 \mathrm{~b}$ & $0.478 \pm 0.02 \mathrm{a}$ & $0.953 \pm 0.04 \mathrm{~b}$ \\
Root dry weight $(\mathrm{g})$ & $0.217 \pm 0.02 \mathrm{~b}$ & $0.105 \pm 0.01 \mathrm{a}$ & $0.200 \pm 0.02 \mathrm{~b}$ \\
Shoot dry weight $(\mathrm{g})$ & $0.651 \pm 0.09 \mathrm{~b}$ & $0.283 \pm 0.03 \mathrm{a}$ & $0.568 \pm 0.01 \mathrm{~b}$ \\
Nodule dry weight $(\mathrm{g})$ & $0.297 \pm 0.05 \mathrm{c}$ & $0.091 \pm 0.02 \mathrm{a}$ & $0.195 \pm 0.02 \mathrm{~b}$ \\
& & & $0.304 \pm 0.06 \mathrm{a}$ \\
Root:shoot & $0.332 \pm 0.02 \mathrm{a}$ & $0.371 \pm 0.01 \mathrm{~b}$ & $31 \pm 8 \mathrm{~b}$ \\
Nodule number & $42 \pm 9 \mathrm{c}$ & $18 \pm 3 \mathrm{a}$ &
\end{tabular}

Values are presented as means \pm SE of separate replicates $(n=4)$. Different letters indicate significant differences between each treatment $(P \leq 0.05)$. 
in a two-fold increase in root, shoot and nodule mass compared to the LP treatment (Table 1). LP plants however, maintained a higher root: shoot ratio, a morphological response typical of low P exposure, but the number of nodules produced was fewer compared to the other two treatments (Table 1).

The RGR for LP and RP roots were similar but significantly less compared to HP. Nodule RGR for RP was restored to levels established with the control (HP) treatment (Table 2). For root and nodule allocation, the response of LP was greater (Table 2), suggesting that more biomass is apportioned towards these organs during P- deprivation.

\section{Concentration and localization of important $N$-fixing elements}

Quantitative micro-PIXE distribution maps of P, K, Ca, Mg, CL, Fe, Al, S, Si, Mo, Mn and $\mathrm{Cu}$ from particle induced x-ray emissions (PIXE) were obtained, but only those elements essential to the process of $\mathrm{N}_{2}$-fixation are presented. In addition to $\mathrm{P}$, these include iron $(\mathrm{Fe})$ and potassium $(\mathrm{K}) . \mathrm{Fe}$ is a component of leghemoglobin that functions in oxygen supply to bacteroids and of the nitrogenase enzyme complex involved in $\mathrm{N}_{2}$-fixation, while $\mathrm{K}$ is important for nodule development.

Elemental maps showed that P concentration did not differ significantly amongst treatments (Figure 2 and 3a). Inorganic phosphate (Pi), the form of $\mathrm{P}$ used for metabolic functioning, was also compared among treatments which indicated that Pi concentration in P-deficient nodules decreased. Following $\mathrm{P}$ deprivation, resupplied nodules seem to recover easily (Figure 4), acquiring Pi at levels analogous to those under HP supply.

The concentration of Fe (Figure 3b) concentration was significantly higher in P-deficient nodules (up to $300 \mathrm{mg} / \mathrm{kg}$ ), compared to HP and RP (Figure 3b). K was distributed in high concentrations with values ranging between 20000 and $30000 \mathrm{mg} / \mathrm{kg}$ throughout nodules 
Figure 2 Representative maps showing the distribution of important N2-fixing elements such as a) phosphorus, iron, and potassium in Virgilia divaricata (Adamson, Fabaceae) nodules grown under adequate (HP), deficient (LP) and resupplied (RP) conditions, obtained using micro-PIXE. Concentrations in mg kg-1 and the scale bars represent $1000 \mu \mathrm{m}$.
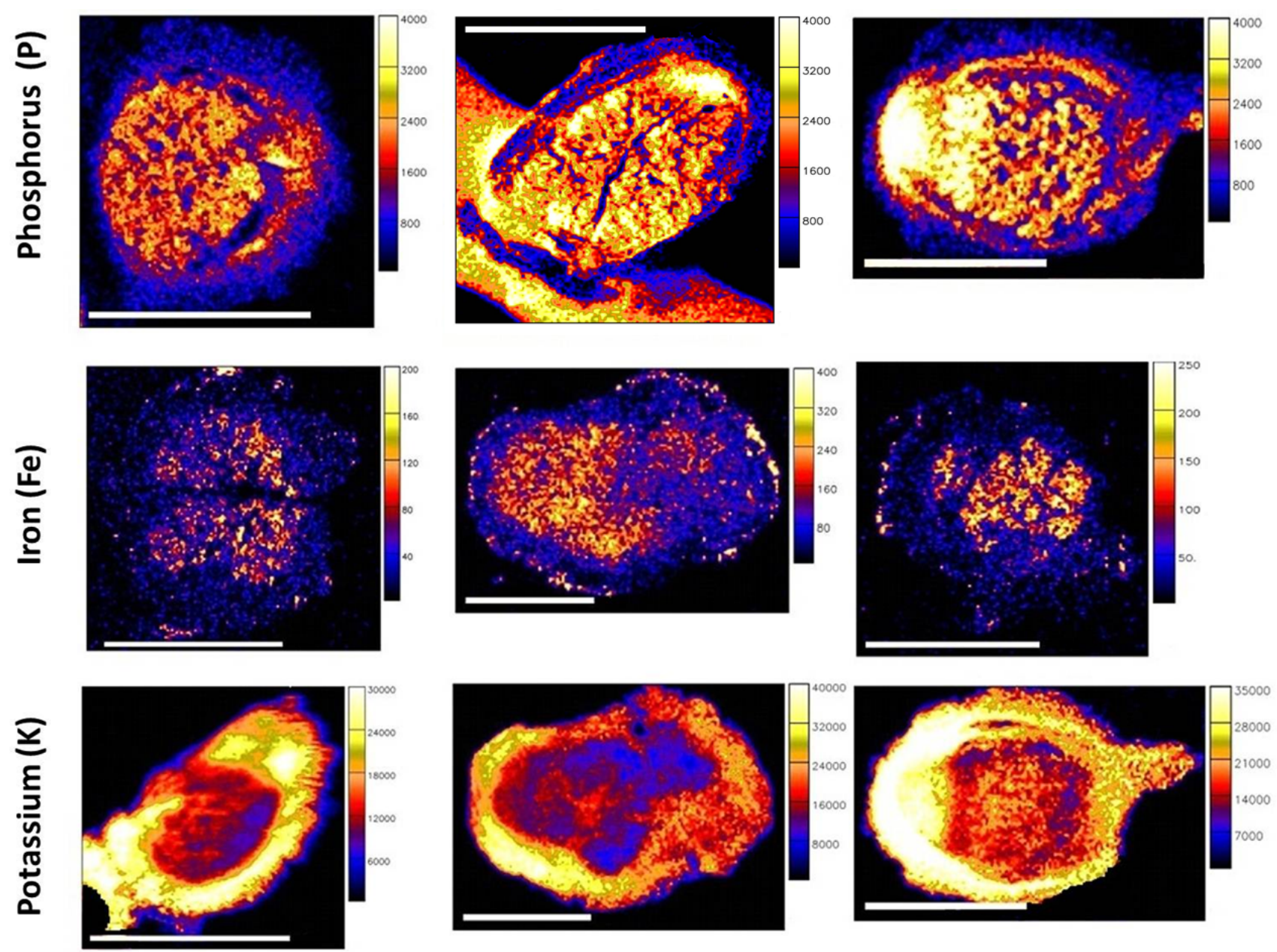

HP $(500 \mu \mathrm{M} P)$

LP $(5 \mu \mathrm{M} \mathbf{P})$

RP $(5 \mu \mathrm{M} ; 500 \mu \mathrm{M} \mathbf{P})$ 


\section{Table 2}

Relative growth rate and allocation of Virgilia divaricata (Adamson, Fabaceae) grown under adequate (HP), deficient (LP) and resupplied (RP) phosphorus conditions.

\begin{tabular}{lccc}
\hline & \multicolumn{3}{c}{ Phosphate treatment } \\
\cline { 2 - 4 } Growth parameter & $\begin{array}{c}\text { High } \\
(500 \mu \mathrm{M}, \text { control })\end{array}$ & $\begin{array}{c}\text { Low } \\
(5 \mu \mathrm{M})\end{array}$ & $\begin{array}{c}\text { Resupplied } \\
(5 \mu \mathrm{M} ; 500 \mu \mathrm{M})\end{array}$ \\
\hline a. Relative growth rate & & & \\
Shoot $\left(\mathrm{mg} \mathrm{g}^{-1} \mathrm{~d}^{-1}\right)$ & $0.055 \pm 0.002 \mathrm{~b}$ & $0.041 \pm 0.001 \mathrm{a}$ & $0.047 \pm 0.002 \mathrm{ab}$ \\
Root $\left(\mathrm{mg} \mathrm{g}^{-1} \mathrm{~d}^{-1}\right)$ & $0.052 \pm 0.002 \mathrm{~b}$ & $0.040 \pm 0.001 \mathrm{a}$ & $0.040 \pm 0.001 \mathrm{a}$ \\
Nodule $\left(\mathrm{mg} \mathrm{g}^{-1} \mathrm{~d}^{-1}\right)$ & $0.057 \pm 0.001 \mathrm{~b}$ & $0.038 \pm 0.001 \mathrm{a}$ & $0.049 \pm 0.001 \mathrm{~b}$ \\
& & & \\
b. Allocation & $0.033 \pm 0.002 \mathrm{a}$ & $0.068 \pm 0.001 \mathrm{~b}$ & $0.032 \pm 0.002 \mathrm{a}$ \\
Root $\left(\mathrm{mg} \mathrm{g}^{-1} \mathrm{~d}^{-1}\right)$ & $0.033 \pm 0.002 \mathrm{a}$ & $0.064 \pm 0.003 \mathrm{~b}$ & $0.039 \pm 0.002 \mathrm{a}$ \\
Nodule $\left(\mathrm{mg} \mathrm{g}^{-1} \mathrm{~d}^{-1}\right)$ & &
\end{tabular}

Values are presented as means \pm SE of separate replicates $(n=4)$. Different letters indicate significant differences between each treatment $(P \leq 0.05)$. 
Figure 3 Micro- PIXE average concentrations of phosphorus, iron and potassium in cross-sections of Virgilia divaricata (Adamson, Fabaceae) nodules grown under adequate (HP), deficient (LP) and resupplied (RP) conditions. Values are presented as means $\pm \mathrm{SE}$ (minimum detection limit) of three separate replicates per treatment.

a)

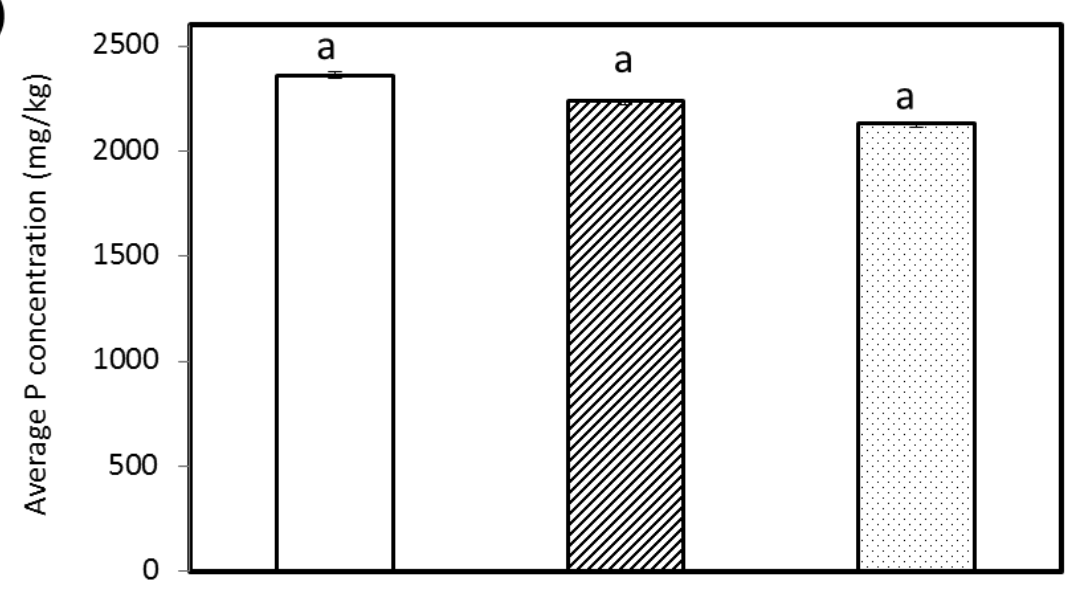

b)

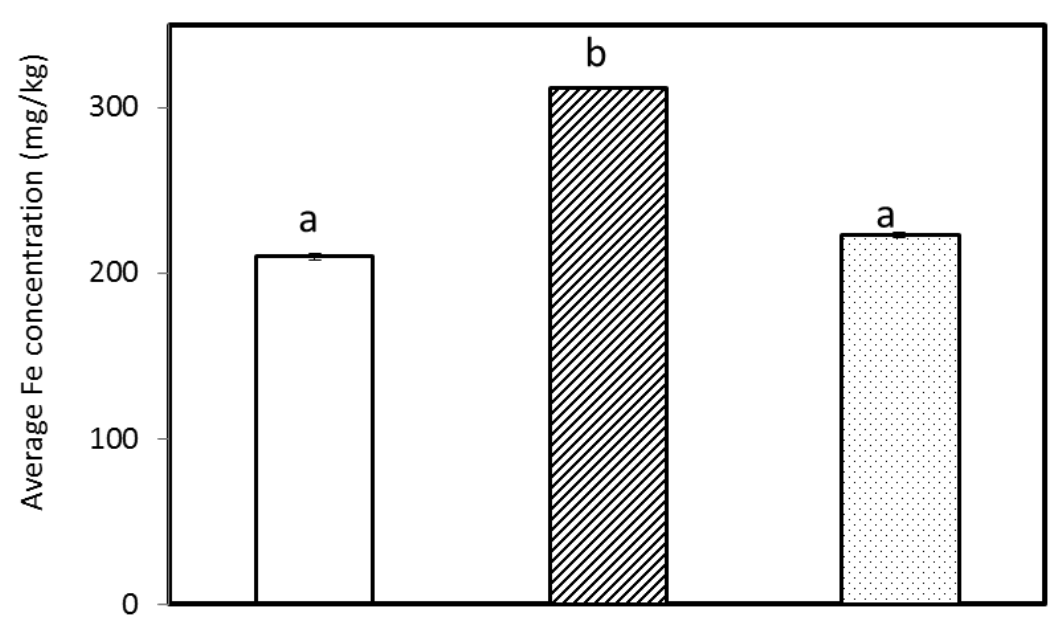

c)

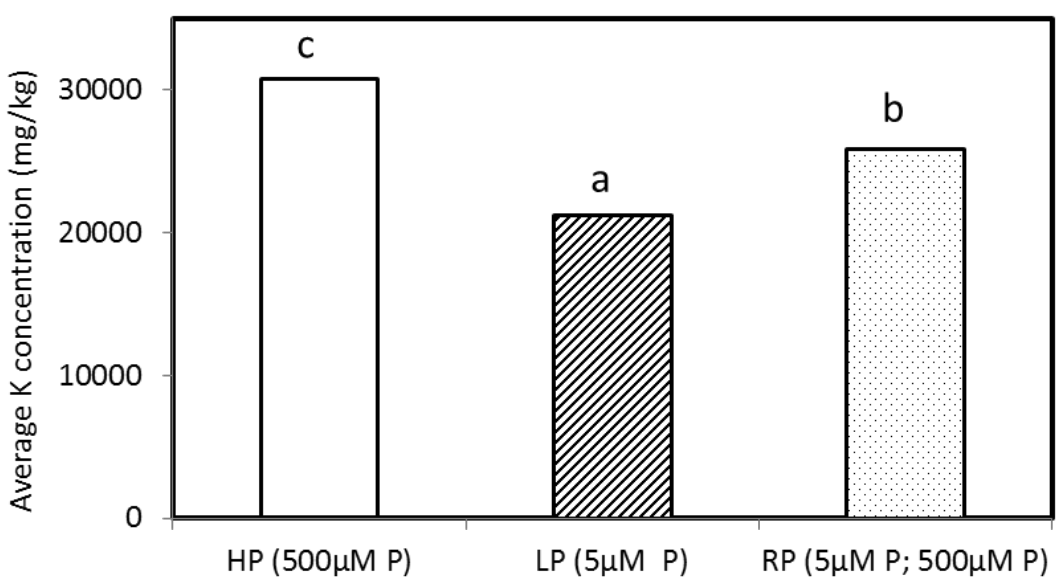


Figure 4 Nodule orthophosphate (Pi), the form used for metabolic functioning in Virgilia divaricata (Adamson, Fabaceae) grown under adequate (HP), deficient (LP) and resupplied (RP) conditions. Values are presented as means \pm SE of separate replicates $(n=5)$. Different letters indicate significant differences between treatments $(P \leq 0.05)$.

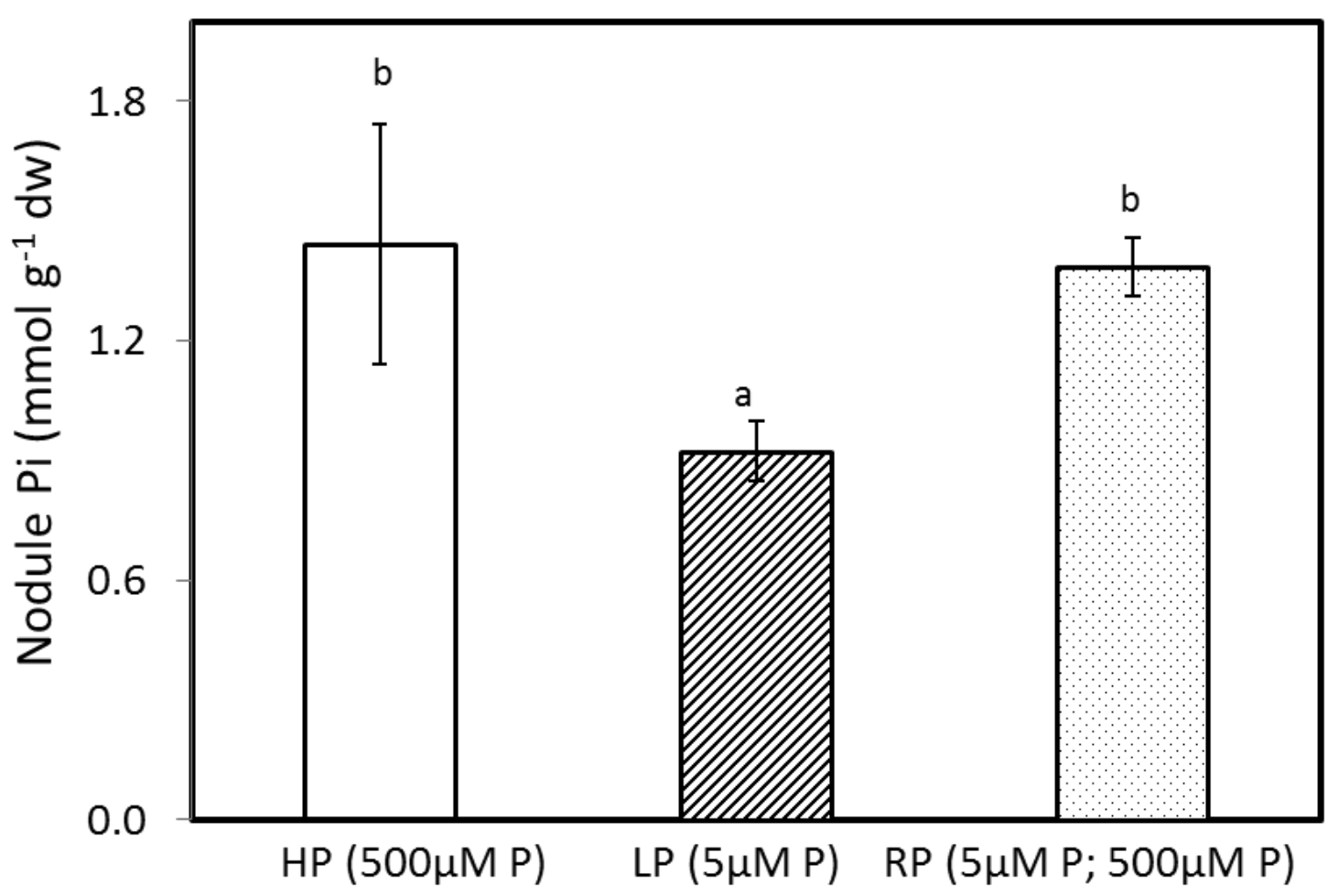


except the deficiency in the central region (Figure 3c) and was highest in P-sufficient and resupplied nodules. This is expected since $\mathrm{K}$ relates to nodule development and number, and P-sufficient plants produced the greatest number of nodules.

Nitrogen and phosphorus nutrition and $N_{2}$ fixation efficiency

The decline of Pi levels in LP nodules (Figure 3 and 4) was accompanied by a decrease in SPAR and SPUR (Table 3). A two-fold increase in root SPUR occurred with P-deprivation but SPAR declined substantially. Resupplied roots recovered to levels found for the control (HP) treatment for both SPUR and SPAR (Table 3). Furthermore, SNAR declined in LP roots but when resupplied, it reached levels similar to HP roots. SNUR in nodules also declined with P-deprivation (Table 3).

Control (HP) plants obtained a greater percentage of $\mathrm{N}$ from the atmosphere compared to LP plants (Figure 5a). However, on a nodule-mass basis, P-deficient plants (and to a lesser extent resupplied plants) were much more efficient at fixing $\mathrm{N}_{2}$ (Figure $5 b$ ).

\section{Acid phosphatase activity}

Greater APase activity was found in P-deficient roots and nodules, than under P-sufficient or resupplied conditions (Figure $6 \mathrm{a}$ and $\mathrm{b}$ ). Roots activity was however greater than nodule activity.

\section{Discussion}

During fluctuations in long-term $\mathrm{P}$ supply, the nodules of $V$. divaricata exhibited both physiological and morphological adaptation to the variations in $\mathrm{P}$ availability. These findings indicate that the legume $V$. divaricata is well adapted to acquire $\mathrm{N}$ during fluctuations in soil $\mathrm{P}$ concentrations, owing to the functional plasticity of its nodule and root physiology. 
Figure 5 a) Percentage nitrogen derived from the atmosphere (\% NDFA) of whole plants and b) biological nitrogen fixation efficiency on a mass basis in nodules, for Virgilia divaricata (Adamson, Fabaceae) grown under adequate (HP), deficient (LP) and resupplied (RP) conditions. Values are presented as means \pm SE of separate replicates. Different letters indicate significant differences between treatments $(\mathrm{P} \leq 0.05)$.
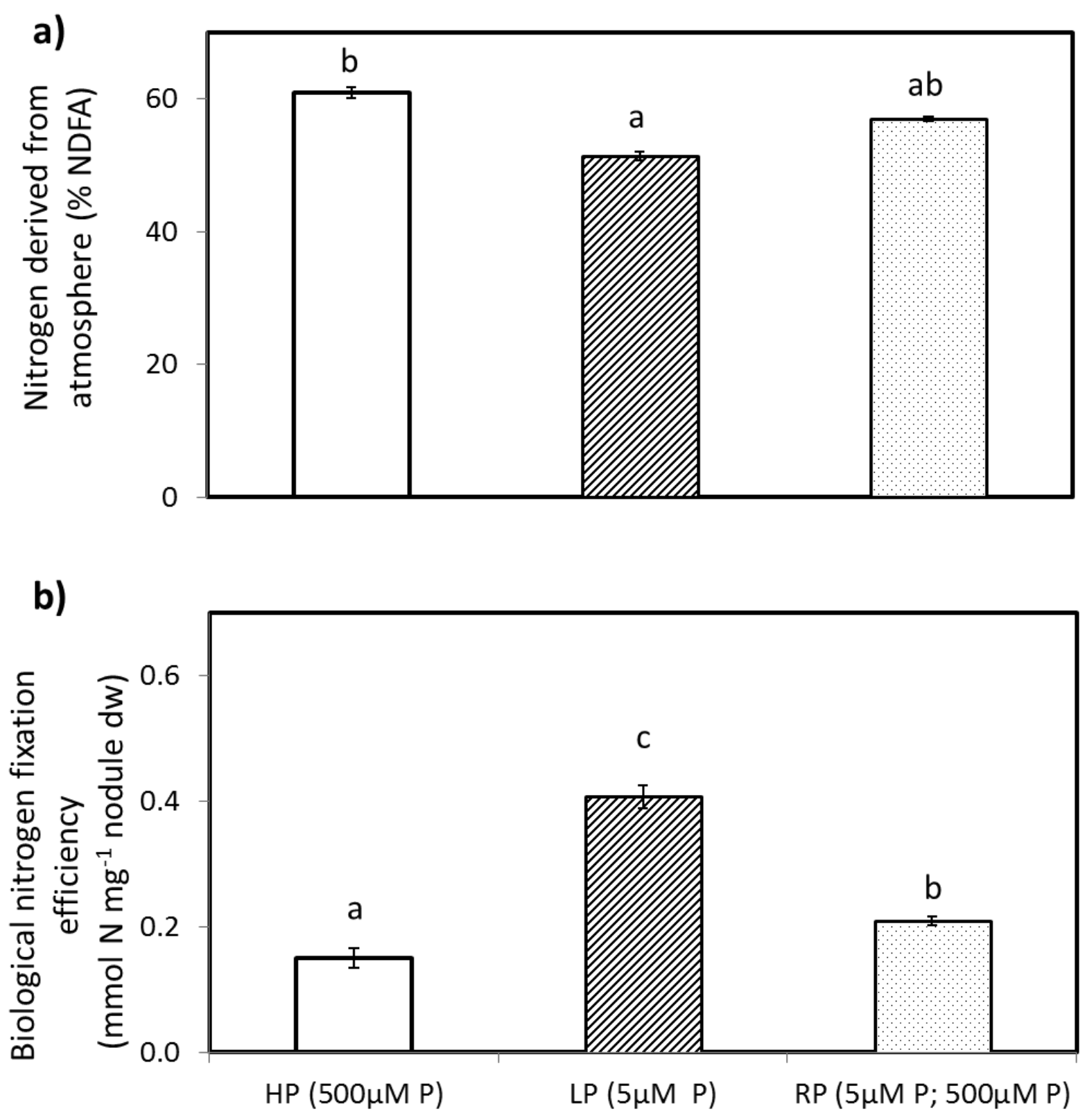
Figure 6 Intracellular acid phosphatase (APase) enzyme activity in Virgilia divaricata(Adamson, Fabaceae) nodules (a) and roots (b) grown under adequate (HP), deficient (LP) and resupplied (RP) conditions. Values are presented as means \pm SE of separate replicates $(n=5)$. Different letters indicate significant differences between treatments $(P \leq 0.05)$.

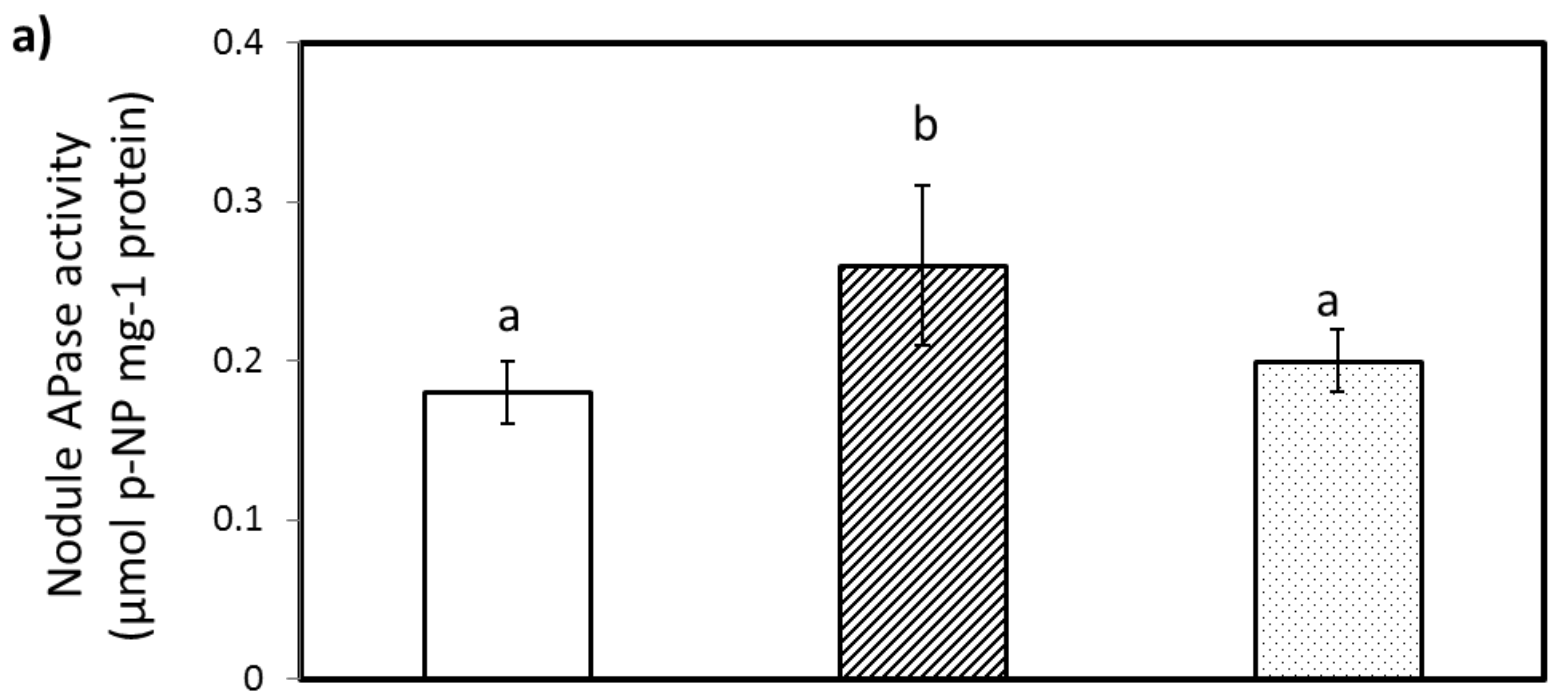

b)

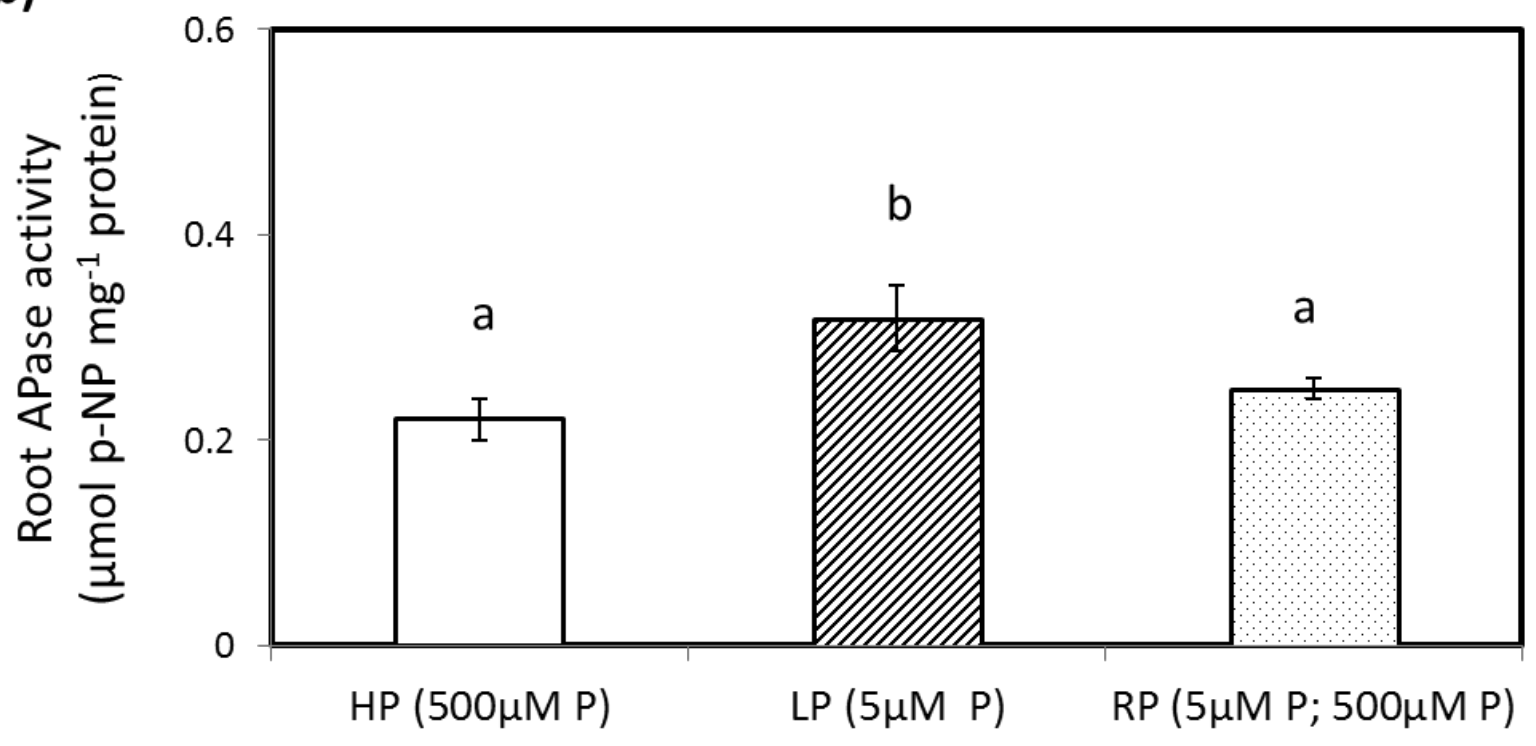




\section{Table 3}

Nitrogen and phosphorus nutritional parameters for Virgilia divaricata (Adamson, Fabaceae) nodules (a) and roots (b) grown under adequate (HP), deficient (LP) and resupplied (RP) conditions.

\begin{tabular}{|c|c|c|c|c|}
\hline \multirow[b]{2}{*}{ Nutrition parameter } & & \multicolumn{3}{|c|}{ Phosphate treatment } \\
\hline & & $\begin{array}{c}\text { High } \\
(500 \mu \mathrm{M}, \text { control }) \\
\end{array}$ & $\begin{array}{c}\text { Low } \\
(5 \mu \mathrm{M})\end{array}$ & $\begin{array}{l}\text { Resupplied } \\
(5 \mu \mathrm{M} ; 500 \mu \mathrm{M})\end{array}$ \\
\hline \multicolumn{5}{|l|}{ a. Nodule } \\
\hline Specific $\mathrm{P}$ absorption rate & $\left(\mathrm{mgP} \mathrm{g}^{-1} \mathrm{DW} \mathrm{d^{-1 }}\right)$ & $0.086 \pm 0.002 b$ & $0.039 \pm 0.001 \mathrm{a}$ & $0.074 \pm 0.001 b$ \\
\hline Specific $\mathrm{N}$ utilization rate & $\left(g d w \mathrm{mg}^{-1} \mathrm{~N} \mathrm{~d}^{-1}\right)$ & $0.018 \pm 0.003 b$ & $0.008 \pm 0.001 a$ & $0.013 \pm 0.000 b$ \\
\hline Specific $P$ utilization rate & $\left(g d w \mathrm{mg}^{-1} P \mathrm{~d}^{-1}\right)$ & $0.026 \pm 0.001 b$ & $0.010 \pm 0.001 a$ & $0.016 \pm 0.000 a$ \\
\hline \multicolumn{5}{|l|}{ b. Root } \\
\hline Specific $\mathrm{N}$ absorption rate & $\left(\mathrm{mgN} \mathrm{g}^{-1} \mathrm{DW} \mathrm{d}^{-1}\right)$ & $0.091 \pm 0.004 b$ & $0.056 \pm 0.006 a$ & $0.080 \pm 0.006 b$ \\
\hline Specific $\mathrm{P}$ absorption rate & $\left.\left(\mathrm{mgP} \mathrm{g}^{-1} \mathrm{DW} \mathrm{d}\right)^{-1}\right)$ & $0.081 \pm 0.002 b$ & $0.027 \pm 0.027 a$ & $0.086 \pm 0.001 b$ \\
\hline Specific $P$ utilization rate & $\left(g d w m^{-1} P^{-1}\right)$ & $0.061 \pm 0.001 \mathrm{a}$ & $0.103 \pm 0.103 b$ & $0.053 \pm 0.000 a$ \\
\hline
\end{tabular}

Values are presented as means \pm SE of separate replicates $(n=4)$. Different letters indicate significant differences between each treatment $(P \leq 0.05)$. 
The recovery responses from P-deficiency observed in this study are similar to earlier reports in which $\mathrm{P}$ supply to previously starved plants, increased plant dry weights progressively (Rao and Terry 1995) and enhanced P uptake (Drew et al., 1984; Jungk et al., 1990). Although these earlier focused on short-term resupply, the current study on $V$. divaricata used a more extended period as it is a slow-growing legume tree. Phosphorus resupply in this legume species after extended low $\mathrm{P}$ conditions provides insight into $\mathrm{P}$ uptake of indigenous legumes in CFR where soils are typically P-poor within a range of concentrations (Stock and Lewis 1986, Witkowski and Mitchell 1987). Moreover, legumes growing in the CFR would have to engage $\mathrm{P}$ conservation and uptake strategies, in order to maintain nodule functioning and sustaining $\mathrm{N}$-metabolism. Under long-term low $\mathrm{P}$ supply $V$. divaricata was able to maintain a high $\mathrm{N}_{2}$-fixing efficiency despite a decline in nodule biomass and metabolic $\mathrm{P} i$ fractions within the nodules. This may have been underpinned by observed adaptations such as the altered nodule biomass allocation, and increased $\mathrm{P}$ recycling and $\mathrm{Fe}$ concentration within nodules.

The increase in the proportion of allocation to both roots and nodules of $V$. divaricata under low P supply, is an adaptive feature in view that altered biomass allocation to root organs is common in plants (Hermans et al., 2006), but less well-known in nodules of legumes. The ability of plants to increase $\mathrm{P}$ uptake under low $\mathrm{P}$ supply is well documented (Shimogawara and Usuda 1995). The enhanced P uptake by P-deficient roots suggests that these plants are adapted to cope with P-deficiency. Under P-deficient and P-resupply conditions, nodule P utilization was analogous but $\mathrm{P}$ absorption differed. P-deficient roots and nodules had a declined P-absorption rate whilst with the resupply treatment rates resembled that of the Psufficient treatment. $\mathrm{P}$ absorption following a period of $\mathrm{P}$ starvation is thought to be concomitant with a higher capacity of roots for $\mathrm{P}$ transport, possibly by the formation of additional carriers and transporters of Pi (Drew et al., 1984, Katz et al., 1986). Under low P 
conditions, Virgilia divaricata maintained an increase in $\mathrm{N}_{2}$-fixing efficiency despite lower levels of total P and Pi in the nodules.

The increased efficiency by nodules under low $\mathrm{P}$ conditions can be attributed to two nutritional factors explored in this study. The first is an increase in Fe concentration and localisation under low $\mathrm{P}$, and the second is the greater $\mathrm{P}$ recycling by APase in both the roots and nodules under low $\mathrm{P}$.

Firstly, the functional significance of the increased Fe concentration in P-deficient nodules is that $\mathrm{Fe}$ is important for the nitrogenase enzyme complex involved in $\mathrm{N}_{2}$-fixation and is a component of leghemoglobin. In pigeon pea nodules, a decline in leghemoglobin was associated with a decline in nitrogenase enzyme activity and lower $\mathrm{N}_{2}$-fixing levels (Nandwal et al., 1991). Legumes exposed to Fe-deficiency develop many nodule initials but few functioning nodules (Tang 1990). Secondly, the importance of the increased APase activity may be related to the role of phosphatase exudation into the rhizosphere, as an important mechanism for ensuring $\mathrm{P}$ acquisition from low $\mathrm{P}$ resources and from forms of $\mathrm{P}$ which are not readily available to other plants (Lambers et al., 2006). Induction of intracellular and secreted acid phosphatase activity has been correlated with de novo acid phosphatase synthesis in several Pi-depleted plants, including Brassica nigra (black mustard), Solanum lycopersicum (tomato), and Arabidopsis suspension cells and seedlings (Duff et al., 1991, Bozzo et al., 2002, Veljanovski et al., 2006). P-deficient roots and nodules exhibited greater APase activity compared to the P-resupply and P-sufficient treatments. The greater activity in roots however, suggests that roots scavenge for $\mathrm{P}$ and transport $\mathrm{P}$ to nodules where nodules conserve $\mathrm{P}$ and typically do not exchange $\mathrm{P}$ with other organs. Nodules are thus strong sinks of P (Hart 1990, Schulze and Drevon 2005). 
Previous studies have also shown that an increase in nodule APase activity may constitute an adaptive mechanism for $\mathrm{N}_{2}$-fixing legumes to tolerate $\mathrm{P}$ deficiency (Kouas et al., 2008, Bargaz et al., 2012). White lupin secretes copious amounts of APases from its roots and proteoid roots when subjected to Pi starvation (Miller et al., 2001, Wasaki et al., 2008). Similarly, common bean nodules increase APase activity under P deficiency (Kouas et al., 2009). Our findings on $V$. divaricata therefore agree with many studies reporting that $\mathrm{P}$ stress induces APase activity, aiding in the internal recycling of $\mathrm{P}$ and the increased APase activity in nodules and roots under P-deficiency, explains the great requirement for P for BNF (Vadez et al., 1997, Al-Niemi et al., 1998).

In conclusion, although prolonged low $\mathrm{P}$ conditions reduced $V$. divaricata growth and the costs of nutrient acquisition, these P-stress responses had sufficient plasticity to revert to normal during $\mathrm{P}$ re-supply. Specifically, the decline in $\mathrm{N}_{2}$-fixation of low $\mathrm{P}$ nodules was compensated for by an increase in BNF efficiency. This can be attributed to increased $\mathrm{Fe}$ concentration, as well as $\mathrm{P}$ recycling by APases. These findings indicate that $V$. divaricata is well-adapted to acquire $\mathrm{N}$ under various conditions of $\mathrm{P}$ availability and contributes to our understanding of legume distribution in nutrient poor regions such as the CFR.

\section{Acknowledgements}

We express gratitude to the technical staff of iThemba Laboratory for Accelerator Based Sciences for assistance with the micro-PIXE measurements and use of their facilities. We also thank the DST-NRF Centre of Excellence in Tree Health Biotechnology (CTHB) for funding, and Aleysia Kleinert, Anathi Magadlela and Moses Siebritz for assistance with plant growth as well as in the laboratory. 


\section{References}

Al-Niemi TS, Kahn ML, McDermott TR. Phosphorus uptake by bean nodules. Plant and Soil 1998; 198: 71-78.

Araújo AP, Plassard C, Drevon JJ. Phosphatase and phytase activities in nodules of common bean genotypes at different levels of phosphorus supply. Plant and Soil 2008; 312: 129-138.

Bargaz A, Ghoulam C, Amenc L, Lazali M, Faghire M, Abadie J, Drevon JJ. A phosphoenol pyruvate phosphatase gene transcript is induced in the root nodule cortex of Phaseolus vulgaris under P deficiency. Journal of Experimental Botany 2012, in press.

Bozzo GG, Raghothama KG, Plaxton WC. Purification and characterization of two secreted purple acid phosphatase isozymes from phosphate-starved tomato (Lycopersicon esculentum) cell cultures. European Journal of Biochemistry 2002; 269: 6278-6286.

Bucciarelli B, Hanan J, Palmquist D, Vance CP. A standardized method for analysis of Medicago truncatula phenotype development. Plant Physiology 2006; 142: 207-219.

Coetsee C, Wigley BJ. Virgilia divaricata may facilitate forest expansion in the afrotemperate forests of the southern Cape, South Africa. Koedoe 2013; 55 http://dx.doi.org/10.4102/ koedoe.v55i1.1128

Doolittle LR. A semiautomatic algorithm for proton backscattering analysis. Nuclear Instruments and Methods in Physics Research Section B - Beam Interactions with Materials and Atoms 1986; 15, 227-231.

Drevon JJ, Hartwig UA. Phosphorus deficiency increases the argon-induced decline of nodule nitrogenase activity in soybean and alfalfa. Planta 1997; 201: 463-469. 
Drew MC, Saker LR, Barber SA, Jenkins W. Changes in the kinetics of phosphate and potassium absorption in nutrient deficient barley roots measured by a solution-depletion technique. Planta 1984; 160: 490-499.

Duff SM, Plaxton WC, Lefebvre DD. Phosphate-starvation response in plant cells: de novo synthesis and degradation of acid phosphatases. Proceedings of the National Academy of Sciences, USA 1991; 88: 9538-9542.

Duff SM, Sarath G, Plaxton WC. The role of acid phosphatases in plant phosphorus metabolism. Physiology Plantarum 1994; 90: 791-800.

Farquhar GD, Ehleringer JR, Hubick KT. Carbon isotope discrimination and photosynthesis. Annual Review of Physiology, Plant and Molecular Biology 1989; 40: 503-537.

Goldblatt P, Manning JC. Plant diversity of the Cape Region of Southern Africa. Annals of the Missouri Botanical Garden 2002; 89: 281-302.

Hammond JP, Bennett MJ, Bowen HC, Broadley MR, Eastwood DC, May ST, Rahn C, Swarup R, Woolaway KE, White PJ. Changes in gene expression in Arabidopsis shoots during phosphate starvation and the potential for developing smart plants. Plant Physiology 2003; 132: 578-596.

Hart AL. Nodule activity and nodule phosphorus in white clover (Trifolium repens) in the presence of mineral nitrogen. Plant Nutrition- Physiology and Applications 1990; 189192p.

He H, Bleby TM, Veneklaas EJ, Lambers H. Dinitrogen-fixing Acacia species from phosphorus-impoverished soils resorb leaf phosphorus efficiently. Plant, Cell and Environment 2011; 34, 2060-2070.

Hermans C, Hammond JP, White PJ, Verbruggen N. How do plants respond to nutrient shortage by biomass allocation? Trends in Plant Science 2006; 11: 610-617. 
Hewitt EJ. Sand and Water Culture Methods used in the Study of Plant Nutrition, 2nd revised Ed. Technical Communication No. 22. Farmham Royal, UK: Commonwealth Agricultural Bureau, 1986; 431-432.

Høgh-Jensen H, Schjoerring JK, Soussana JF. The influence of phosphorus deficiency on growth and nitrogen fixation of white clover plants. Annals of Botany 2002; 90: 745-753.

Israel DW. Investigation of the role of phosphorus in symbiotic dinitrogen fixation. Plant Physiology 1997, 84: 835-840.

Israel DW. Symbiotic dinitrogen fixation and host-plant growth during development of and recovery from phosphorus deficiency. Physiology Plantarum 1993; 88: 294-300.

Jungk A, Asher CJ, Edwards DG, Meyer D. Influence of phosphate status on phosphate uptake kinetics of maize (Zea mays) and soybean (Glycine max). Plant Soil 1990; 124: 175182.

Katz DB, Gerloff GC, Gabelman WH. Effects of phosphate stress on the rate of phosphate uptake during resupply to deficient tomato plants. Physiology Plantarum 1986; 67:23-28.

Kouas S, Louche J, Debez A, Plassard C, Drevon JJ, Abdelly C. Effect of phosphorus deficiency on acid phosphatase and phytase activities in common bean (Phaseolus vulgaris L.) under symbiotic nitrogen fixation. Symbiosis 2009; 47: 141-149.

Kouas S, Alkama N, Abdelly C, Drevon JJ. Proton release by nodulated roots varies among common bean genotypes (Phaseolus vulgaris) under phosphorus deficiency. Journal of Soil Science and Plant Nutrition 2008; 171: 242-248.

Lambers H, Shane MW, Cramer MD, Pearse SJ, Veneklaas EJ. Root structure and functioning for efficient acquisition of phosphorus: Matching morphological and physiological traits. Annals of Botany 2006; 98: 693-713. 
Le Roux MR, Kahn S, Valentine AJ. Organic acid accumulation inhibits N2-fixation in Pstressed lupin nodules. New Phytologist 2008; 177: 956-964.

Le Roux MR, Ward CL, Botha FC, Valentine AJ. The route of pyruvate synthesis under Pi starvation in legume root systems. New Phytologist 2006; 169: 399-408.

Magadlela A, Kleinert A, Dreyer L, Valentine AJ. Low-phosphorus conditions affect the nitrogen nutrition and associated carbon costs of two legume tree species from a Mediterranean-type ecosystem. Australian Journal of Botany 2014; 62, 1-9.

Marschner H. Mineral Nutrition of Higher Plants 1995, 2nd ed. New York: Academic Press. Miller SS, Liu J, Allan DL, Menzhuber CJ, Fedorova M, Vance CP. Molecular control of acid phosphatase secretion into the rhizosphere of proteoid roots from phosphorus-stressed white lupin. Plant Physiology 2001; 127: 594-606.

Morgan JAW, Bending GD, White PJ. Biological costs and benefits to plant-interactions in the rhizosphere. Journal of Experimental Botany 2005; 56: 1729-1739.

Nandwal AS, Bharti S, Sheoran IS. Drought effects on carbon exchange and nitrogen-fixation in pigeon pea (Cajanus cajan L). Journal of Plant Physiology 1991; 138: 125-127.

Olczak M, Morawiecka B, Wątorek W. Plant purple acid phosphatases - genes, structures and biological function. Acta Biochimica Polonica 2003; 50: 1245-1256.

Olivera M, Tejera N, Iribarne C, Ocaña A, Lluch C. Growth, nitrogen fixation and ammonium assimilation in common bean (Phaseolus vulgaris): effect of phophorus. Physiologia Plantarum 2004; 121: 498-505.

Plaxton WC. Plant responses to stress: biochemical adaptation to phosphorus deficiency. In: Goodman RM, ed. Encyclopedia of Plant and Crop Science. Marcel Dekker, New York 2004. pp. 976-980. 
Prozesky VM, Przybylowicz WJ, Van Achterbergh E, Churms CL, Pineda CA, Springhorn KA, Pilcher JV, Ryan CG, Kritzinger J, Schmitt H, Swart T. The NAC nuclear microprobe facility. Nuclear Instruments and Methods in Physics Research Section B - Beam Interactions with Materials and Atoms 1995; 104: 36-42.

Przybylowicz W.J., Mesjasz-Przybylowicz J., Migula P., et al., 2005. Micro-PIXE in ecophysiology. X-ray Spectrometry 34: 285-289.

Przybylowicz WJ, Mesjasz-Przybylowicz J, Pineda CA, Churms CL, Ryan CG, Prozesky VM, Frei R, Slabbert JP, Padayachee J, Reimold WU. Elemental mapping using protoninduced X-rays. X-ray Spectrometry 2001; 30: 156-163.

Przybylowicz WJ, Mesjasz-Przybylowicz J, Pineda CA, Churms CL, Springhorn KA, Prozesky VM. Biological applications of the NAC nuclear microprobe. X-ray Spectrometry 1999; 28: 237-243.

Raghothama KG. Phosphate acquisition. Annual Review of Plant Physiology and Plant Molecular Biology 1999; 50: 665-693.

Rao IM, Terry N. Leaf phosphate status, photosynthesis, and carbon partitioning in sugar beet. IV. Changes with time following increased supply of phosphate to low-phosphate plants. Plant Physiology 1995; 107:1313-1321.

Ryan CG. Quantitative trace element imaging using PIXE and the nuclear microprobe. International Journal of Imaging Systems and Technology 2000; 11: 219-230.

Schulze J, Adgo E, Merbach W. Carbon costs associated with N2 fixation in Vica faba L. and Pisum sativum L. over a 14-day period. Plant Biology 1999; 1: 625-631.

Schulze J, Drevon JJ. P-deficiency increases the $\mathrm{O}_{2}$ uptake per $\mathrm{N}_{2}$ reduced in alfalfa. Journal of Experimental Botany 2005; 56: 1779-1784. 
Schulze J., Temple G., Temple S.J., Heidrun B. \& Vance C. 2006. Nitrogen fixation by white lupin under phosphorus deficiency. Annals of Botany 98: 731-740.

Shearer G.B. \& Kohl D.H. 1986. $\mathrm{N}_{2}$-fixation in field settings: estimations based on natural ${ }^{15} \mathrm{~N}$ abundance. Australian Journal of Plant Physiology 13: 699-756.

Shimogawara K. \& Usuda H. 1995. Uptake of inorganic phosphate by suspension-cultured tobacco cells: kinetics and regulation by Pi starvation. Plant and Cell Physiology 36:341-351.

Somasegaran P. \& Hoben H.J. 1994. Handbook for Rhizobia - methods in legumerhizobium technology. Springer-Verlag.

Stock WD, Lewis OAM. Soil nitrogen and the role of fire as a mineralizing agent in a South African coastal fynbos ecosystem. Journal of Ecology 1986; 74:317-328.

Sulieman S, Van Ha C, Schulze J, Tran L. Growth and nodulation of symbiotic Medicago truncatula at different levels of phosphorus availability. Journal of Experimental Botany 2013; 64: 2701-2712.

Tang C, Hinsinger P, Drevon JJ, Jaillard B. Phosphorus deficiency impairs early nodule functioning and enhances proton release in roots of Medicago truncatula L. Annals of Botany 2001; 88: 131-138.

Tang C, Robson AD, Dilworth MJ. The role of iron in nodulation and nitrogen fixation in Lupinus angustifolius L. New Phytologist 1990; 114: 173-182.

Thuynsma R, Valentine A, Kleinert A. Phosphorus deficiency affects the allocation of belowground resources to combined cluster roots and nodules in Lupinus albus. Journal of Plant Physiology 2014; 171: 285-291. 
Vadez V, Beck DP, Lasso JH, Drevon JJ. Utilization of the acetylene reduction assay to screen for tolerance of symbiotic $\mathrm{N} 2$ fixation to limiting $\mathrm{P}$ nutrition in common bean. Physiologia Plantarum 1997; 99: 227-232.

Vadez V, Sinclair TR. Leaf ureide degradation and N2 fixation tolerance to water deficit in soybean. Journal of Experimental Botany 2001; 52: 153-159

Valentine AJ, Benedito VA, Kang Y. Legume nitrogen fixation and soil abiotic stress: from physiology to genomics and beyond. Annual Plant Reviews 2010; 42: 207-248

Vance CP, Udhe-Stone C, Allan DL. Phosphorus acquisition and use: critical adaptation by plants for securing a non-renewable resource. New Phytologist 2003; 157, 423-447.

Veljanovski V, Vanderbeld B, Knowles VL, Snedden WA, Plaxton WC. Biochemical and molecular characterization of AtPAP26, a vacuolar purple acid phosphatase up-regulated in phosphate-deprived Arabidopsis suspension cells and seedlings. Plant Physiology 2006;142: $1282-1293$.

Wasaki J, Kojima S, Maruyama H, Haase S, Osaki M, Kandeler E. Localization of acid phosphatase activities in the roots of white lupin plants grown under phosphorus-deficient conditions. Soil Science and Plant Nutrition 2008; 54: 95-102.

Witkowski ETF, Mitchell DT. Variations in soil phosphorus in the fynbos biome, South Africa. Journal of Ecology 1997; 75:1159-1171.

Yadav R, Tarafdar J. Influence of organic and inorganic phosphorus supply on the maximum secretion of acid phosphatase by plants. Biology and Fertility of Soils 2001; 34: 140-143. 